\title{
Trends in stratospheric ozone derived from merged SAGE II and Odin-OSIRIS satellite observations
}

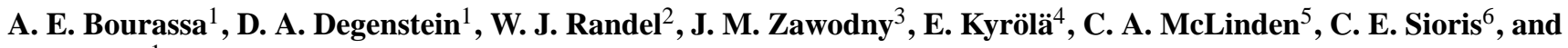 \\ C. Z. Roth $^{1}$ \\ ${ }^{1}$ Institute of Space and Atmospheric Studies, University of Saskatchewan, Saskatoon, Canada \\ ${ }^{2}$ National Center for Atmospheric Research, Boulder, CO, USA \\ ${ }^{3}$ NASA Langley Research Center, Hampton, VA, USA \\ ${ }^{4}$ Finnish Meteorological Institute, Earth Observation Unit, Helsinki, Finland \\ ${ }^{5}$ Environment Canada, Downsview, Ontario, Canada \\ ${ }^{6}$ Department of Earth and Space Science and Engineering, York University, Toronto, Canada
}

Correspondence to: A. E. Bourassa (adam.bourassa@usask.ca)

Received: 6 February 2014 - Published in Atmos. Chem. Phys. Discuss.: 18 March 2014

Revised: 27 May 2014 - Accepted: 2 June 2014 - Published: 9 July 2014

\begin{abstract}
Stratospheric ozone profile measurements from the Stratospheric Aerosol and Gas Experiment (SAGE) II satellite instrument (1984-2005) are combined with those from the Optical Spectrograph and InfraRed Imager System (OSIRIS) instrument on the Odin satellite (2001-Present) to quantify interannual variability and decadal trends in stratospheric ozone between $60^{\circ} \mathrm{S}$ and $60^{\circ} \mathrm{N}$. These data are merged into a multi-instrument, long-term stratospheric ozone record (1984-present) by analyzing the measurements during the overlap period of 2002-2005 when both satellite instruments were operational. The variability in the deseasonalized time series is fit using multiple linear regression with predictor basis functions including the quasi-biennial oscillation, El Niño-Southern Oscillation index, solar activity proxy, and the pressure at the tropical tropopause, in addition to two linear trends (one before and one after 1997), from which the decadal trends in ozone are derived. From 1984 to 1997 , there are statistically significant negative trends of 5-10\% per decade throughout the stratosphere between approximately 30 and $50 \mathrm{~km}$. From 1997 to present, a statistically significant recovery of 3-8\% per decade has taken place throughout most of the stratosphere with the notable exception between $40^{\circ} \mathrm{S}$ and $40^{\circ} \mathrm{N}$ below approximately $22 \mathrm{~km}$ where the negative trend continues. The recovery is not significant between 25 and $35 \mathrm{~km}$ altitudes when accounting for a conservative estimate of instrument drift.
\end{abstract}

\section{Introduction}

The variability of stratospheric ozone and the trends observed in past decades continue to be of importance for understanding the future evolution of ozone and its interaction with changing climate. The analysis of various data sets toward this end has been a focus of research for nearly three decades. An improved understanding of chemical depletion processes has led to predictions of complete future recovery of the ozone layer by 2050 at the earliest (WMO, 2011). Several recent studies have highlighted the need for high-quality, altitude-resolved profile measurements to quantify the different aspects of atmospheric variability and trends throughout the global stratosphere. Satellite measurements are elemental to these analyses (for example, see Weatherhead et al., 2000, Randel and Wu, 2007; Randel and Thompson, 2011; Kyrölä et al., 2012). One of the key data sets in many past studies is that of ozone profile measurements made by the Stratospheric Aerosol and Gas (SAGE) II satellite instrument, which obtained high-quality, vertical profiles of the global stratosphere by solar occultation from 1984 to 2005. In this paper we use the ozone profile measurements made by the Optical Spectrograph and InfraRed Imaging System (OSIRIS) on the Odin satellite, which began in 2002, to extend the SAGE II record to the present day. The OSIRIS ozone profile data set, obtained through measurements of limb-scattered sunlight spectra, have similar quality and vertical resolution as the SAGE II measurements, and extend 
from the upper tropopause to the upper stratosphere. Also, OSIRIS provides retrievals of ozone density on altitude levels, similar to SAGE II, so that conversions from the mixing ratio on pressure surfaces is not needed. The 4-year overlap between the two missions allows for robust comparison and analysis to merge the two measurement sets. The goal of this paper is twofold: to demonstrate the feasibility of merging the SAGE II and OSIRIS ozone measurements into a single time series through comparative analysis of the two time series and, secondly, to use the merged time series to quantify interannual variability and trends in stratospheric ozone from 1984 to 2013 over the latitude range $60^{\circ} \mathrm{S}-60^{\circ} \mathrm{N}$. The OSIRIS instrument is currently still fully operational and this merged time series will continue to provide long-term monitoring of these trends into the future. This work follows directly from the recent results of Sioris et al., 2013, who analyzed the SAGE II and OSIRIS time series in the tropical lower stratosphere only.

\section{Data set descriptions}

The SAGE II instrument, operational from 1984 to 2005, measured solar transmittance in the ultraviolet, visible and near infrared wavelength ranges in order to infer profiles of ozone number density and other stratospheric trace gases and aerosol (McCormick et al., 1989). The profiles extend from below $15 \mathrm{~km}$ to above $50 \mathrm{~km}$ with $1 \mathrm{~km}$ resolution, are reported on a regular $0.5 \mathrm{~km}$ altitude grid, and have relatively sparse sampling in a latitudinal distribution that varies slowly over the course of weeks to months to cover the globe. The ozone product version used here is version 7.0 (Damadeo et al., 2013), which, compared to the previous standard product version 6.2, features decreased retrieval smoothing, updated absorption cross sections (Bogumil et al., 2003), and atmospheric temperature and pressure from Modern-Era Retrospective Analysis for Research and Applications (MERRA; Rienecker et al., 2011). The outlier removal, including filtering for high values of volcanic aerosol, has been updated from Wang et al., 2002. See Damadeo et al, 2013, for details on the SAGE II version 7.0 data product. As noted by Kyrölä et al., 2013, among others, the requirements for stability of the measurements for this type of trend analysis are stringent. High quality for the SAGE II occultation measurements is achieved via a self-calibration through the observation of the direct sun at the beginning or end of the occultation on a sunset or sunrise measurement, respectively.

The OSIRIS instrument began standard stratospheric limb scattered sunlight measurements in early 2002, shortly after launch on the Odin satellite in 2001 (Llewellyn et al, 2004; Murtagh et al., 2002; McLinden et al., 2012) and remains fully operational at the present time. The spectra, which cover the $280-800 \mathrm{~nm}$ wavelength range, are used in combination with a spherical radiative transfer model that accounts for multiple scattering (Bourassa et al., 2008) and a non-linear relaxation inversion to retrieve profiles of ozone number density from 10 to $60 \mathrm{~km}$ altitudes with approximately $2 \mathrm{~km}$ vertical resolution and successive samples about every $500 \mathrm{~km}$ along the polar orbit track (Degenstein et al., 2009). Although the limb scatter technique does not measure the sun directly, the retrieval method provides a similar selfcalibration of the measurement through normalization of the spectral radiance by the measurement at the same wavelength at a higher tangent altitude above the retrieval range. This effectively decreases the dependence on the effective scene albedo (von Savigny et al., 2003) and helps to increase the long-term stability of the retrieved product in a similar fashion to the self-calibration of the occultation measurement. The polar orbit, which is nominally 18:00 local time at the ascending node, provides global coverage during spring and fall, and coverage of the tropics throughout the year. No measurements are obtained during polar winter. In this work, for which we have used the version 5.07 data set, only OSIRIS measurements on the descending orbit track, i.e., near local dawn, are used as the slight procession of the orbit to later local times has resulted in the loss of coverage in the tropics on the ascending node after 2004.

\section{Analysis and results I: merged ozone anomaly time series}

Previous work comparing OSIRIS and SAGE II ozone observations has shown generally excellent agreement between the two data sets during the 4-year overlap period. Adams et al., 2013, performed a detailed comparison of coincident measurements and found the absolute value of the resulting mean relative difference profile is $<5 \%$ for $13-55 \mathrm{~km}$ and $<3 \%$ for $24-54 \mathrm{~km}$. Generally the OSIRS data were found to have a slightly higher bias around $22 \mathrm{~km}$, particularly at higher latitudes.

The long-term stability of the 11-year OSIRIS data set was comprehensively characterized and assessed by Adams et al., 2014, who used the Microwave Limb Sounder (MLS) and Global Ozone Monitoring by Occultation of Stars (GOMOS) satellite data records in addition to and ozonesonde measurements. The results of this work show that the mean percent differences between coincident measurements are within 5\% at all altitudes above $18.5 \mathrm{~km}$ for MLS, above $21.5 \mathrm{~km}$ for GOMOS, and above $17.5 \mathrm{~km}$ for ozonesondes. The stability analysis found that global average drifts relative to the validation data sets are $<3 \%$ per decade in comparison with MLS for $19.5-36.5 \mathrm{~km}$, GOMOS for $18.5-54.5 \mathrm{~km}$, and ozonesondes for 12.5-22.5 km. Adams et al., 2014, concluded that the 11-year OSIRIS data set is suitable for trend analysis.

Even in light of these encouraging results, the relatively long 4-year overlap between the SAGE II and OSIRIS measurements is an essential factor in the ability to reliably merge these data sets into a single time series for the assessment of decadal trends, particularly since post-2000 SAGE 


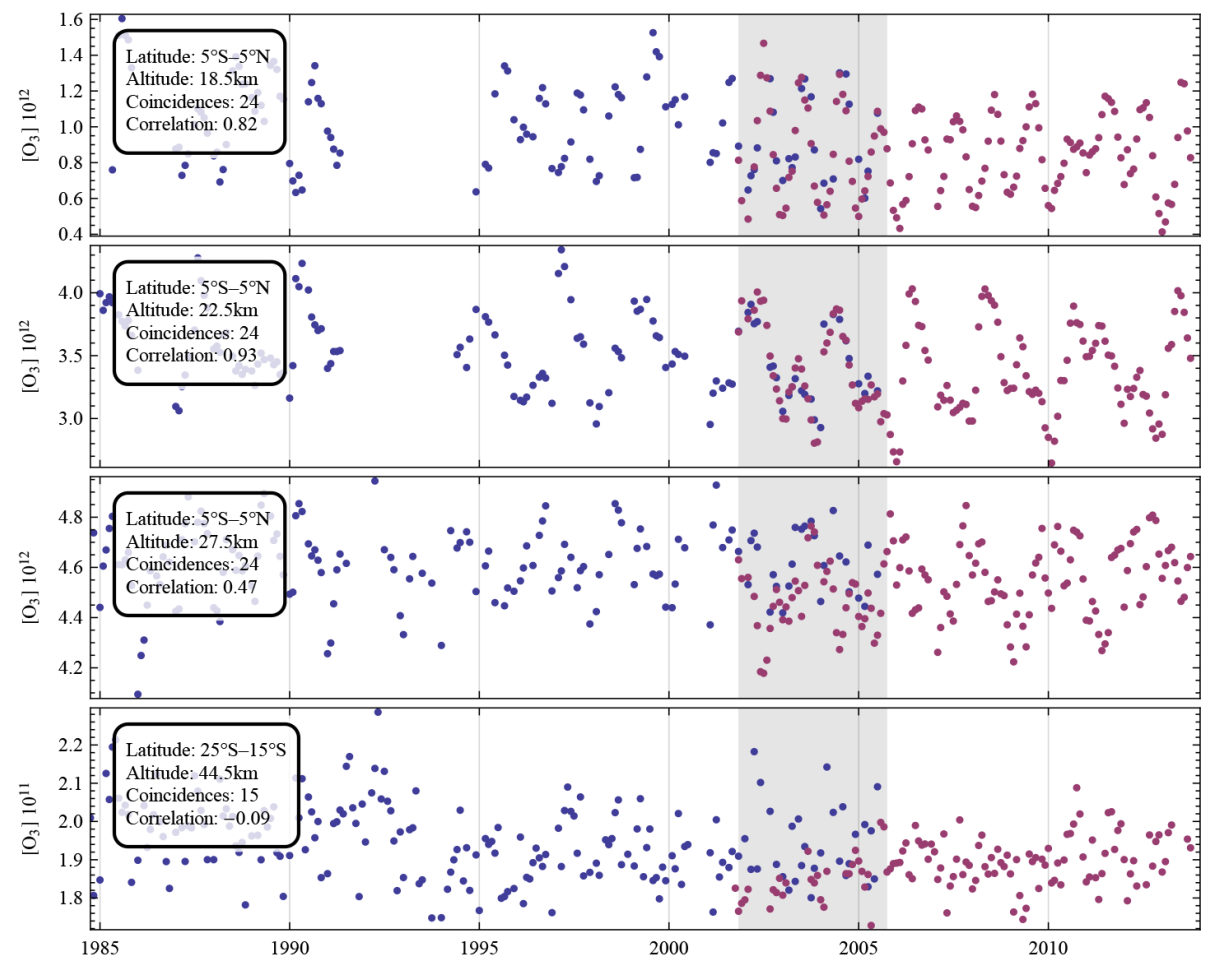

Figure 1. Time series of monthly average ozone number density in latitude and altitude bins. The grey shaded area denotes the overlap time between the start of OSIRIS measurements (shown in red) and end of the SAGE II measurements (shown in blue). Note the changing scale on the vertical axes.

II was capturing only one occultation per orbit. Similarly, as both instruments retrieve ozone number density on an altitude grid, there is no need for unit and/or vertical co-ordinate conversions that can bias ozone trends if the simultaneous trends in temperature are not properly accounted for (McLinden and Fioletov, 2011). For the purposes of this paper, monthly mean ozone number density time series were calculated for both instruments in $10^{\circ}$ latitude bins from $60^{\circ} \mathrm{S}$ to $60^{\circ} \mathrm{N}$ and in $1 \mathrm{~km}$ altitude bins. Extending the analysis to higher latitudes is limited by the lack of OSIRIS sampling in polar winter. The raw agreement in the monthly averaged ozone number density can be seen from the sample time series shown for four different latitude-altitude bins in Fig. 1. The top panel, Fig. 1a, at $18.5 \mathrm{~km}$ in the tropics shows the strong seasonal cycle that is observed by both instruments just above the tropical tropopause. The second panel, Fig. 1b, at $22.5 \mathrm{~km}$ shows the dominant quasi-biennial oscillation (QBO) signal in the tropical lower stratosphere. For slightly higher altitudes at $27.5 \mathrm{~km}$, the QBO signal becomes weaker as shown in the third panel, Fig. 1c. The lowest panel, Fig. 1d, corresponding to $44.5 \mathrm{~km}$ altitude and $15^{\circ}-25^{\circ} \mathrm{S}$, is more typical of the upper stratosphere where weak signal variation results in poor correlation despite approximate agreement between the two instruments. Overall the time series show similar sized, in-phase, cyclic variations. Somewhat larger differences can be found, particularly at altitudes above $40 \mathrm{~km}$, when comparing to SAGE II sunrise or sunset measurements separately, or with smaller latitudinal or temporal bins.

For most of the stratosphere there is a high correlation (greater than 0.9) between the two time series during the overlap period as shown in Fig. 2. Regions in the lower stratosphere where the correlation decreases (circled and marked "a" in the plot) correspond to regions where the overall cyclic variability in the time series is much smaller. This can be seen by comparing the magnitude of the cyclic variability of the time series in Fig. 1c to those at lower altitudes in Fig. 1a and b. These same regions also correspond to low values of normalized standard deviation in the middle panel of Fig. 2. The decreased variability results in lower values of correlation despite good agreement in monthly mean values, which agree to within typically $5 \%$ throughout the stratosphere as shown in the bottom panel of Fig. 2. This is a similar level of agreement found by detailed coincidence comparisons (Adams et al., 2013). OSIRIS has a slightly higher bias for latitudes south of $50^{\circ} \mathrm{S}$, which extends throughout stratospheric altitudes and lasts throughout the austral summer. OSIRIS also shows a slightly larger negative bias below $20 \mathrm{~km}$ between $40^{\circ} \mathrm{S}$ and $40^{\circ} \mathrm{N}$. The circled region marked "b" in the correlation plot, as well as the rest of the upper stratosphere where the correlation is not as high, are regions where there are very little seasonal or QBO signals in the 
SAGE II / OSIRIS Monthly number density correlation

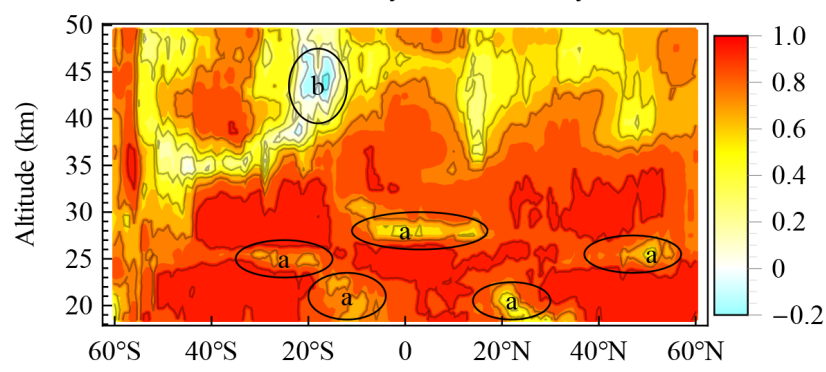

Normalized standard deviation in monthly number density
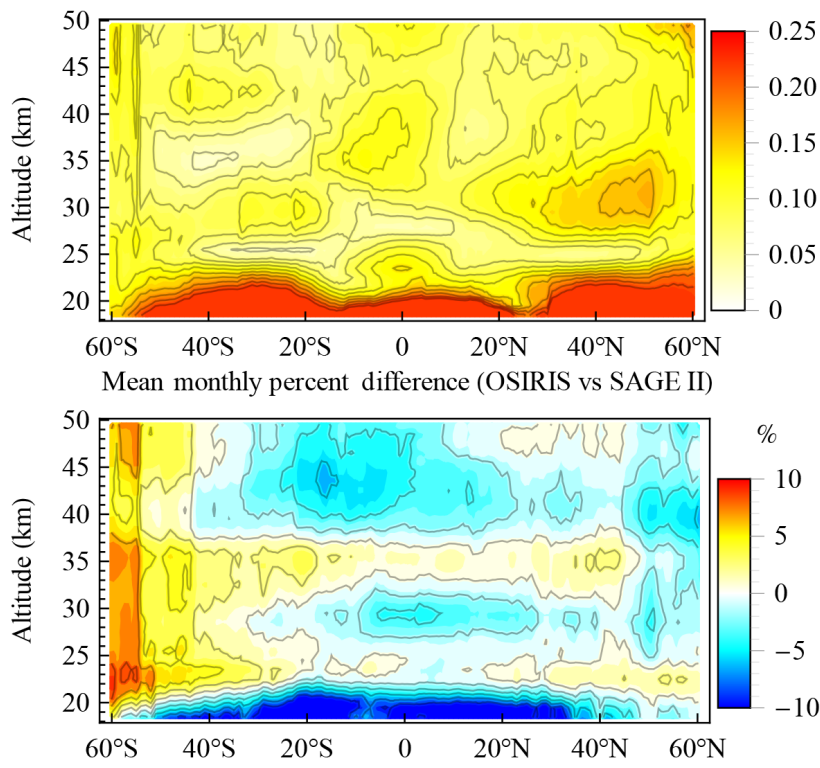

Figure 2. Top: correlation between SAGE II and OSIRIS monthly mean during the overlap period 2002-2005. Middle: standard deviation of the time series, including measurements from both instruments during the overlap period, normalized to the monthly mean. Bottom: percent difference between the SAGE II and OSIRIS monthly mean over the same period. Encircled regions marked "a" and "b" denote decreased correlation due to lower amplitude seasonal and QBO variability.

time series, again leading to reduced correlation even though the monthly mean values are in good agreement (see Fig. 1d).

A merged time series of the deseasonalized ozone anomaly was created by combining the two data sets. To perform the deseasonalization, climatological means are found for each month by averaging for each instrument independently; this accounts for any small difference in the observed seasonal cycles, as done previously in other studies (Jones et al., 2009; Randel and Thompson, 2011). These means are determined using the entire time span of each data set, i.e., from 1984 to 2005 for SAGE II, and 2002 to 2013 for OSIRIS. Sample deseasonalized anomaly time series for each instrument, independently, are shown in Fig. 3 for the same locations as those shown in the panels in Fig. 1. Note that this technique results in a zero average value for the time series of each in- strument. The final merged time series was determined by shifting the OSIRIS time series at each latitude and altitude by the difference between OSIRIS and SAGE II during the overlap period, and then averaging the two time series in any bin that contains a point from both OSIRIS and SAGE II. The values that are used to shift the OSIRIS anomalies to match those of SAGE II during the overlap period are quite small, typically less than $3 \%$.

The resulting merged and deseasonalized time series is shown as a function of altitude and time for several latitude bins in Fig. 4. Missing data due to lack of sufficient sampling or screening of the data for contamination from the large volcanic eruptions is shown in white. Particularly in the tropics there is the clear signature of the downward propagating signal of the QBO. Note the approximate change in phase of this signal above $\sim 27 \mathrm{~km}$, which is related to the change from dynamical to chemical control of stratospheric ozone around this altitude level as reported by several other studies in the past (for example, Randel and Thompson, 2011; Chipperfield et al., 1994). In this figure, the beginning and end of the instrument overlap period is marked with vertical black lines; however, the consistency of the observed structures across these time periods fosters confidence in the quality of the merged data set. Note that even by eye, a broad minimum in ozone can be seen in each latitude bin between 1994 and 2005, particularly in the upper stratosphere.

\section{Analysis and results II: time series analysis and decadal trends}

We have used a standard linear multi-variate regression analysis to quantify the variability and trends in the merged and deseasonalized SAGE II-OSIRIS time series. We have included standard predictor variable basis functions representing the solar cycle $(\mathrm{F} 10.7 \mathrm{~cm}$ index from ftp://ftp.ngdc.noaa.gov/stp/solar_data/solar_radio/flux/ penticton_adjusted/daily), the El Niño-Southern Oscillation (ENSO) from the multivariate ENSO index (MEI) obtained from the NOAA Climate Diagnostics Center (Wolter, 2013), deseasonalized tropical tropopause pressure from the $\mathrm{Na}$ tional Centers for Environmental Prediction (NCEP), and the QBO (http://www.geo.fu-berlin.de/en/met/ag/strat/produkte/ qbo/index.html; Naujokat, 1986). Typically, QBO variability is fit based on two orthogonal QBO time series that can be used in linear combination to represent the QBO at all pressure levels (Wallace et al., 1993; Randel and Wu, 1996). We have used a principal component analysis to generate the first three principal components of the QBO. As shown in the results of the regression below, the third component is a smaller amplitude, high-frequency term that accounts for a small fraction of the observed ozone variability, approximately on the same order as the solar cycle proxy. Each of these predictor variable basis functions is shown in Fig. 5. 


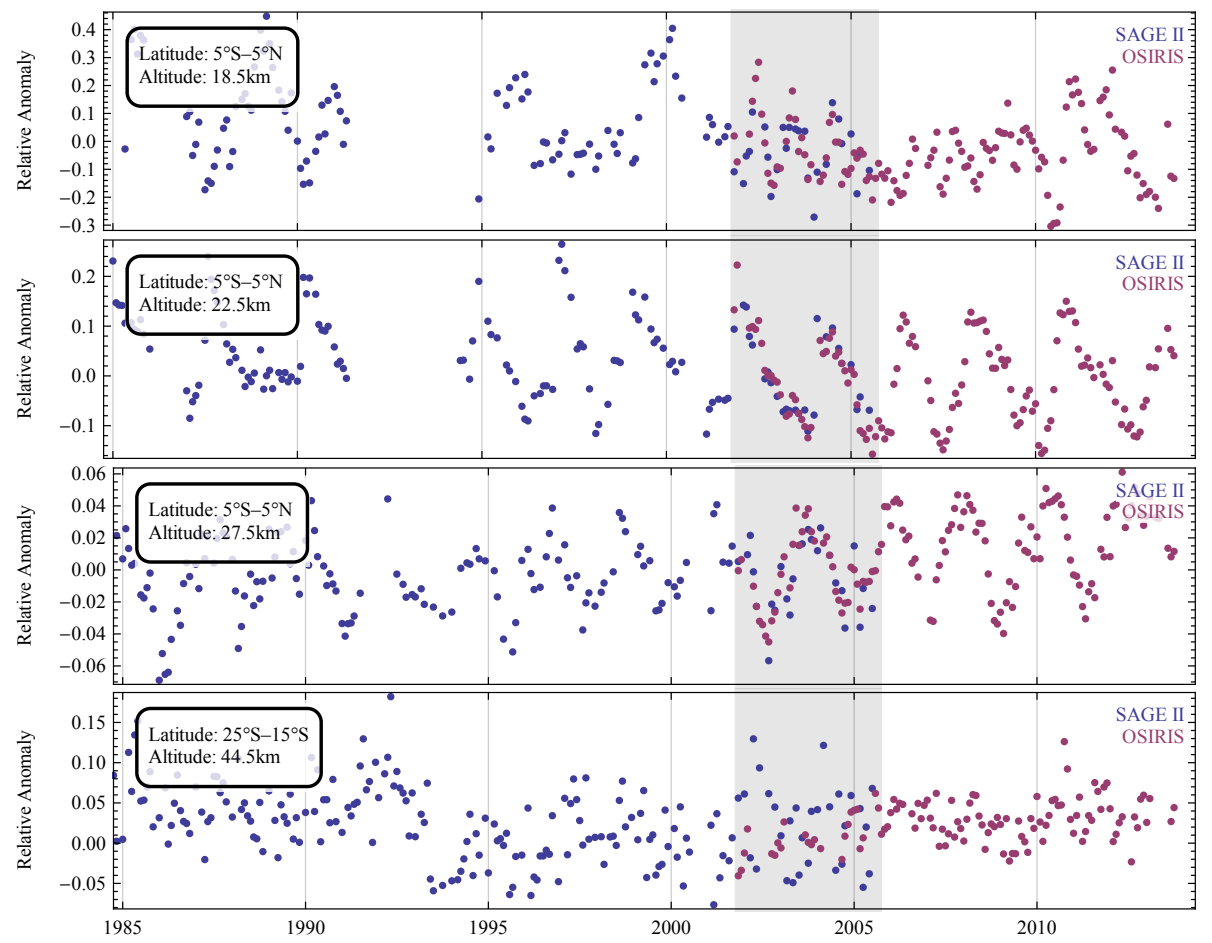

Figure 3. Deseasonalized ozone anomaly at the same locations as Fig. 1 calculated for each instrument independently. In the top panel, the strong seasonal cycle observed just above the tropical tropopause has been effectively removed. The remaining variability is mostly due to the QBO and tropopause pressure. At high altitudes in the tropical stratosphere, shown in the second and third panels, the QBO signal dominates the anomaly. For the upper stratosphere, shown in the bottom panel, the QBO signal has greatly decreased.

The ENSO index is used with a 2 month lag as done previously (see, for example, Randel and Thompson, 2011).

For simplicity of interpretation, we have also used a piecewise linear term to account for long-term changes in the stratosphere, particularly the changes in equivalent effective stratospheric chlorine (EESC). The time of the inflection point of this piece-wise term, corresponding to the "turnaround" time, or the beginning of ozone recovery, has been fixed at 1997. This is discussed in some detail in several studies including Kyrölä et al., 2013, Laine et al., 2013, Newchurch et al., 2003, and Jones et al., 2009, with overall agreement on the choice of 1997. This has also been the decision of the $\mathrm{SI}^{2} \mathrm{~N}$ working group for the trend analysis for the 2014 WMO (World Meteorological Organization) ozone assessment (Harris et al., 2014, in preparation). The estimate of the uncertainty in the results of the regression analysis is determined using a bootstrap resampling technique, with 1 year time of granularity. This estimate includes the effects of serial autocorrelation (Efron and Tibshirani, 1993; Randel and Thompson, 2011).

All altitude/latitude bins are analyzed independently with no smoothing between the bins. Results of the regression analysis for chosen altitude and latitude bins are shown in detail in Figs. 6-8. In each column of these figures, the uppermost panel shows the ozone anomaly in blue and resulting fit in red. The middle panel shows the pre- and post-1997 linear terms in percent per decade, and the six predictor basis functions multiplied by their normalized best-fit parameters, which are shown numerically along with each curve. The lower panel contains the residual ozone anomaly. The left panel in Fig. 6 corresponds to the tropics at $18.5 \mathrm{~km}$ altitude; cf. Figs. 1a and 3a. At this location negative trends in ozone are apparent both before and after 1997 with a relatively strong correlation to tropopause pressure and ENSO. The right panel corresponds to the tropics at $22.5 \mathrm{~km}$ altitude, cf. Figs. $1 \mathrm{~b}$ and $3 \mathrm{~b}$, with smaller but still negative linear trends both before and after 1997. Here the ozone anomaly contains a very strong QBO signature from the first two principal components. In Fig. 7, the left panel corresponds to the tropics at $27.5 \mathrm{~km}$ altitude; cf. Figs. $1 \mathrm{c}$ and $3 \mathrm{c}$. At this location a small positive linear trend is observed after 1997 and the QBO indices are the dominant terms in the fit. The right panel corresponds to $25^{\circ} \mathrm{S}-15^{\circ} \mathrm{S}$ at $44.5 \mathrm{~km}$ altitude; cf. Figs. 1d and 3d, where significant recovery of $5.1 \%$ per decade is observed after 1997 following a decrease of $-5.9 \%$ per decade prior to 1997. In Fig. 8, the left panel corresponds to $45^{\circ}-35^{\circ} \mathrm{S}$ at $42.5 \mathrm{~km}$ altitude where the strongest changes between pre- and post-1997 linear trends occur. This same latitude and altitude shows the strongest changes in the Northern Hemisphere (NH) as well. The right panel corresponds to $5^{\circ} \mathrm{S}-5^{\circ} \mathrm{N}$ at $32.5 \mathrm{~km}$ altitude. In this region, the linear trends are reversed in direction compared to the 

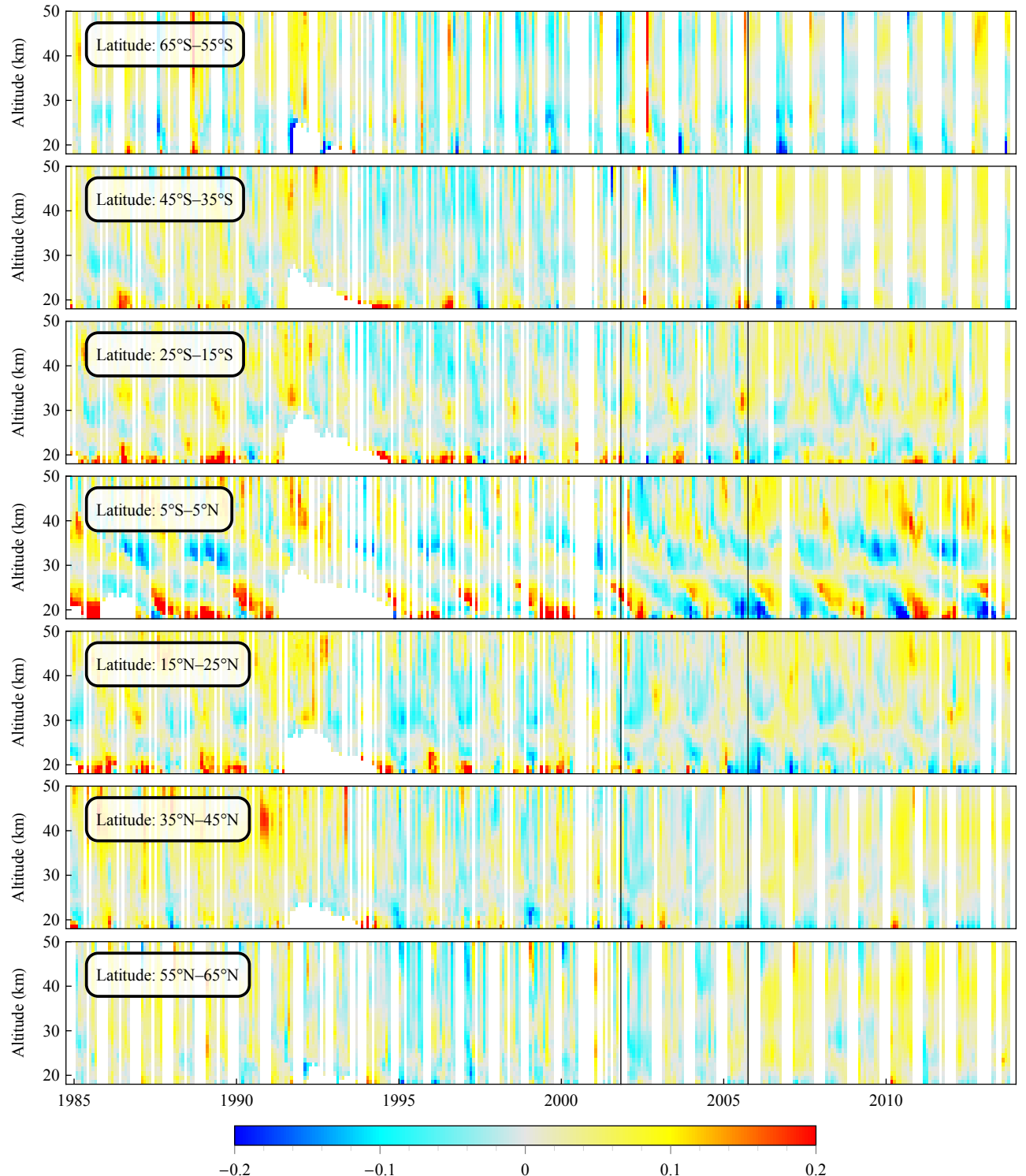

Figure 4. Merged relative ozone anomaly for selected latitude bins. The overlap period is indicated with the black bars. Missing profiles, shown in white, occur when neither instrument samples a given month. Other periods of missing data confined to the lower stratosphere are due to screening of the SAGE II data for high aerosol extinction during large volcanic eruptions. The magnitude of the relative ozone anomaly is strongest over the tropics, where the downward propagating QBO signature is clear. In each latitude bin, a broad minimum in ozone can be seen between 1994 and 2005, particularly in the upper stratosphere.

remainder of the stratosphere, but are statistically insignificant. In many of these cases, the fit residual variability is large and does not appear completely random; this is consistent with previous studies and remains not well understood (Randel and Thompson, 2011). Also, residuals appear larger for the SAGE II part of the record in some places (example Fig. 8, left panel), probably because of the relatively sparser SAGE II sampling.

The relative contribution and spatial structure of each of the fitted predictor basis functions is shown in Fig. 9 as relative ozone change per one standard deviation of each param- eter for the QBO principal components, tropical tropopause pressure, ENSO index and solar proxy. Regions that are not statistically significant at the $95 \%$ level are indicated with overlaid grey stippling. The QBO is a significant term throughout the stratosphere with well-known out-of-phase patterns between the tropics and middle latitudes (Randel and $\mathrm{Wu}, 2007)$. As noted above, the third principal component is small but significant in places. The solar cycle proxy is also small but significant in the middle and upper stratosphere in the Southern Hemisphere. The overall pattern matches that reported by Kyrölä et al., 2013, from analysis of a merged 

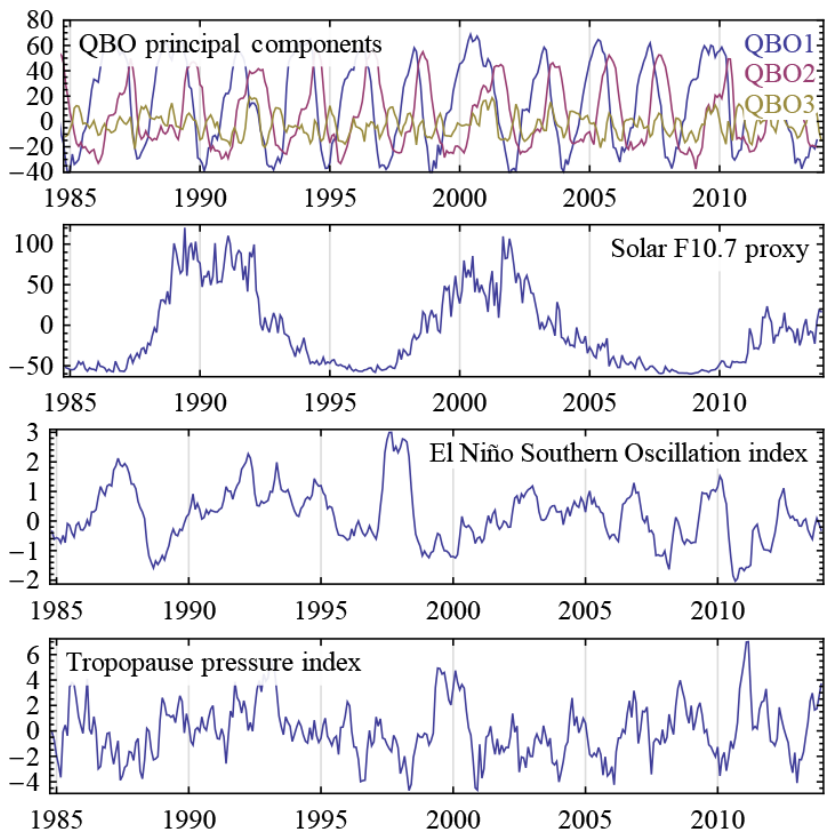

Figure 5. The six non-linear basis functions used to fit the ozone anomaly. From top down: the first three principal components of the multi-level QBO; the F10.7 solar proxy; the El Niño-Southern Oscillation index with a two month lag; deseasonalized tropopause pressure.

SAGE II-GOMOS time series, except at $50-60^{\circ} \mathrm{N}$ where the GOMOS analysis shows a larger influence of the solar cycle. Both the ENSO index and the tropical tropopause pressure have relatively strong and significant projections in the tropical lower stratosphere in the opposite sense (ENSO index is negative, and tropopause pressure is positive). This is likely linked to the fact that both ozone and temperature changes are caused by enhanced tropical upwelling in ENSO warm events (Randel et al., 2009; Calvo et al., 2010). The ENSO projection also shows out-of-phase patterns in the NH midlatitude lower stratosphere, corresponding to ozone enhancements during ENSO warm events (consistent with observations of column ozone over midlatitudes; e.g., Bronnimann et al, 2004).

The results from the piece-wise linear fit for the pre- and post-1997 time periods are shown in Fig. 10. From 1984 to 1997, there are statistically significant negative trends of 5$10 \%$ per decade throughout the stratosphere, except over the tropics between 22 and $34 \mathrm{~km}$, where there is a small insignificant positive trend. Significant recovery of 3-8\% per decade from 1997 to present is observed throughout the majority of the stratosphere. Recovery is also not observed in the tropics between 25 and $35 \mathrm{~km}$ where there is a small insignificant negative trend. The largest positive trends are observed in the upper stratosphere above $35 \mathrm{~km}$. Our results show a distinct hemispherical asymmetry in the recovery with the strongest positive trends at southern latitudes between 20 and $45^{\circ} \mathrm{S}$.

\section{Summary and discussion}

These results derived from the merged SAGE II-OSIRIS data agree in general with the results from the SAGE IIGOMOS time series analysis performed by Kyrölä et al., 2013. The altitude and latitude structure of the results are very similar. The negative trends also match very well in terms of magnitude. However, the asymmetry in the recovery in our result is not also in the GOMOS result and the magnitude of the recovery is not as high as we find with the OSIRIS data set. The GOMOS analysis shows significant recovery only for $38-45 \mathrm{~km}$ altitudes at a rate of $1-2 \%$ per decade and does not find the decreasing trend post-1997 in the tropical lower stratosphere. There also seems to be a systematic decrease in the GOMOS post-1997 trends for both northern and southern latitudes above $40^{\circ}$ that does not arise in the OSIRIS analysis performed here. These differences may be explained in part by the small drifts, essentially $<3 \%$ per decade, detected by Adams et al., 2013, in the comparisons between OSIRIS GOMOS, and MLS. Although the drift patterns are not the same between OSIRIS and the other two instruments there are some noteworthy similarities including positive drifts with respect to the other instruments in the tropics throughout stratospheric altitudes, and negative drifts in the southern extratropics. The OSIRIS-GOMOS analysis shows a region of higher positive drift south of $40^{\circ} \mathrm{S}$ and above $40 \mathrm{~km}$ altitude, and stronger positive drifts (>5\% per decade) in the extratropics below $20 \mathrm{~km}$ altitude. Because the drift analysis remains uncertain and more comprehensive comparisons with other instruments and ground-based measurements need to be done, we have chosen not to directly modify the resulting trends, but have attempted to account for any potential drift by adding $3 \%$ per decade in quadrature to the bootstrap uncertainties. This is shown in Fig. 11 where the grey stippling to indicate the significance of the trend has been recalculated in this fashion. In general, the recovery above $35 \mathrm{~km}$ remains significant; however all trends in the altitude range of $25-35 \mathrm{~km}$ are insignificant with conservative drift estimates taken into account. The decreasing trend in the lower stratosphere also remains significant.

Other recent studies of long-term satellite measurements have reported stratospheric ozone trends by similar analyses, though not by merging with the SAGE II measurements. Gebhardt et al., 2014, derived trends using SCIAMACHY (SCanning Imaging Absorption spectroMeter for Atmospheric CHartographY) measurements alone from 2002 to 2012. The broad pattern of recovery in the upper stratosphere is consistent with our results, including the hemispheric asymmetry that shows stronger recovery in the Southern Hemisphere. However, the SCIAMACHY results show strong, significant, negative trends of up to $-20 \%$ per decade in the tropics between 30 and $35 \mathrm{~km}$, and up to $-10 \%$ per decade in the Northern Hemisphere middle latitudes between 25 and $35 \mathrm{~km}$ that are not in agreement with our results. Additionally, the SCIAMACHY analysis does 


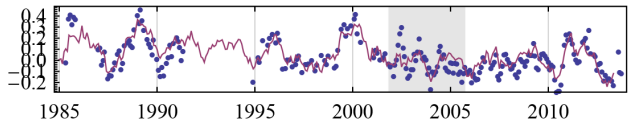

(a)
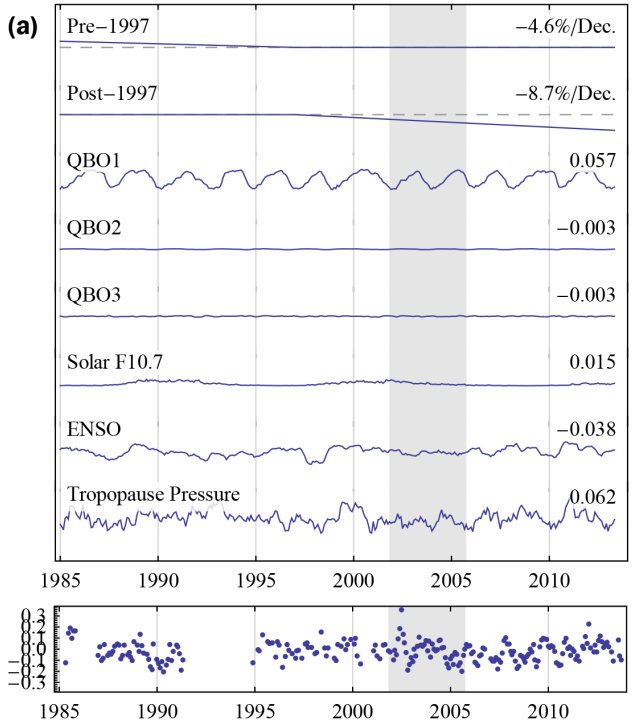

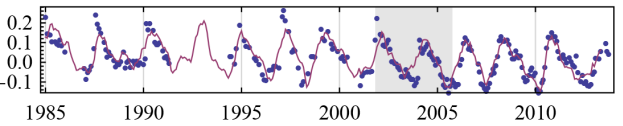

(b)

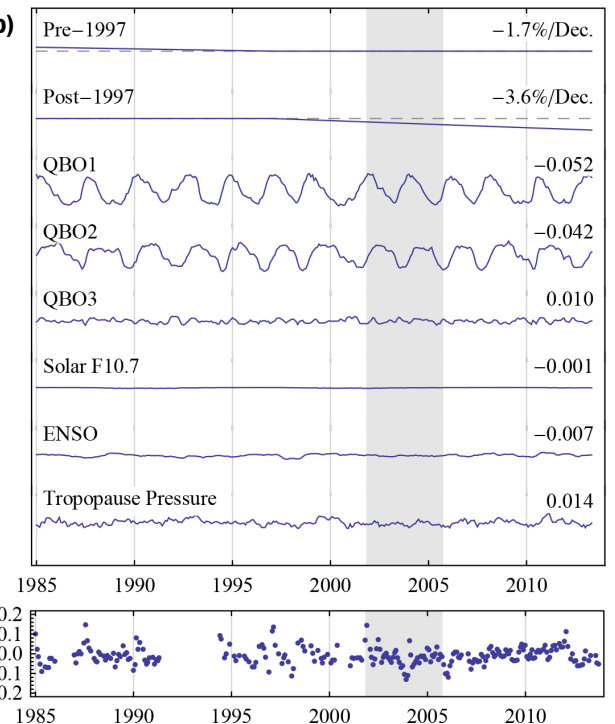

Figure 6. In each column, the uppermost panel shows the ozone anomaly in blue and resulting fit in red for a given latitude and altitude. The middle panel shows the pre- and post-1997 percent per decade linear terms, and the six non-linear basis functions multiplied by their normalized best-fit parameters (shown on the right of each curve). The basis functions are shown on the same scale as the ozone anomaly. These terms sum to form the resulting fit. The lower panel contains the residual ozone anomaly. Left: $5^{\circ} \mathrm{S}-5^{\circ} \mathrm{N}$ at $18.5 \mathrm{~km}$ altitude (cf. Figs. 1a, 3a). At this location negative trends in ozone are apparent both before and after 1997 with a relatively strong correlation to tropopause pressure and ENSO. Right: $5^{\circ} \mathrm{S}-5^{\circ} \mathrm{N}$ at $22.5 \mathrm{~km}$ altitude (cf. Fig. $1 \mathrm{~b}, 3 \mathrm{~b}$ ) with a smaller but still negative correlation both before and after 1997.
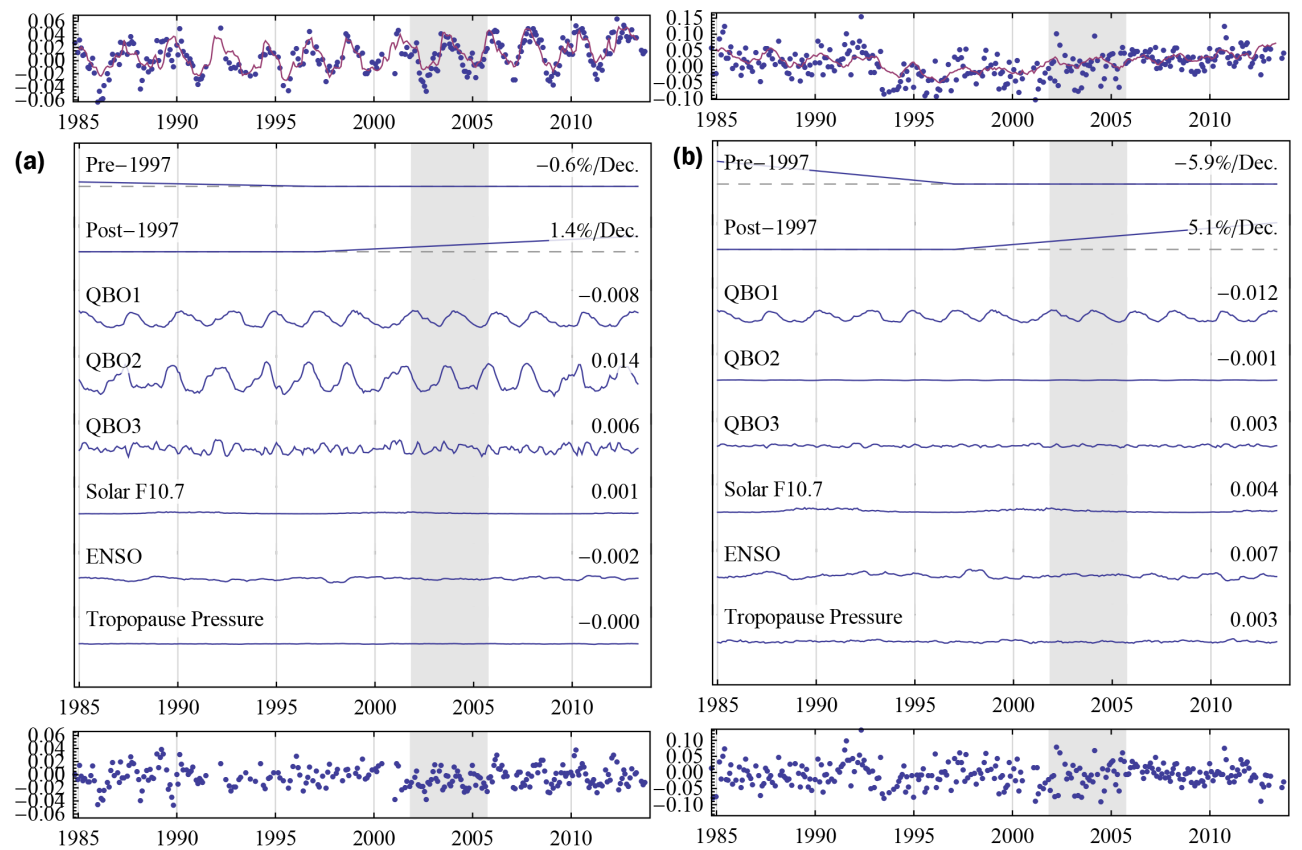

$1985 \quad 1990 \quad 1995 \quad 2000 \quad 2005 \quad 2010$

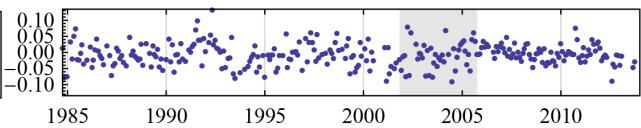

Figure 7. Same as Fig. 6. Left: $5^{\circ} \mathrm{S}-5^{\circ} \mathrm{N}$ at $27.5 \mathrm{~km}$ altitude (cf. Figs. 1c, 3c). A small positive linear trend is observed after 1997. The QBO indices are the dominant terms. Right: $25^{\circ} \mathrm{S}-15^{\circ} \mathrm{S}$ at $44.5 \mathrm{~km}$ altitude (cf. Figs. 1d, 3d). Significant recovery of $5.1 \%$ per decade is observed after 1997 following a decrease of $-5.9 \%$ per decade prior to 1997 . 


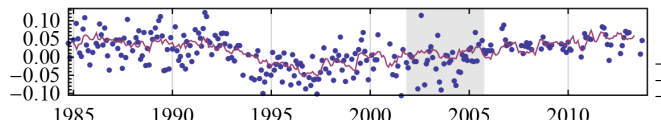

(a)

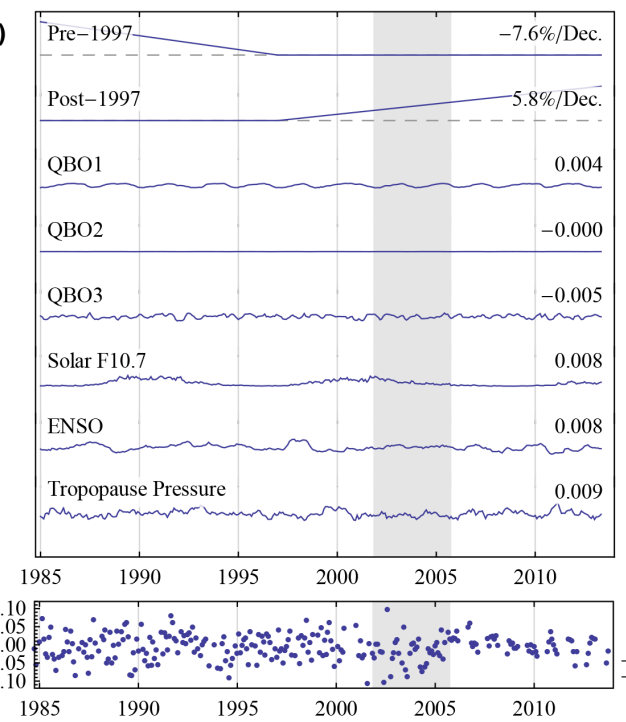

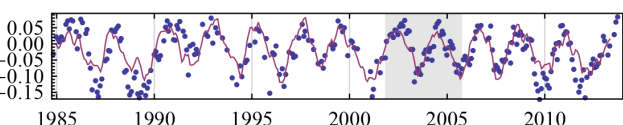

(b) \begin{tabular}{lllll}
1985 & 1990 & $1995 \quad 2000$ & 2005 & 2010 \\
\hline$P r e-1997$ & & $1.0 \% / \mathrm{Dec}$
\end{tabular}

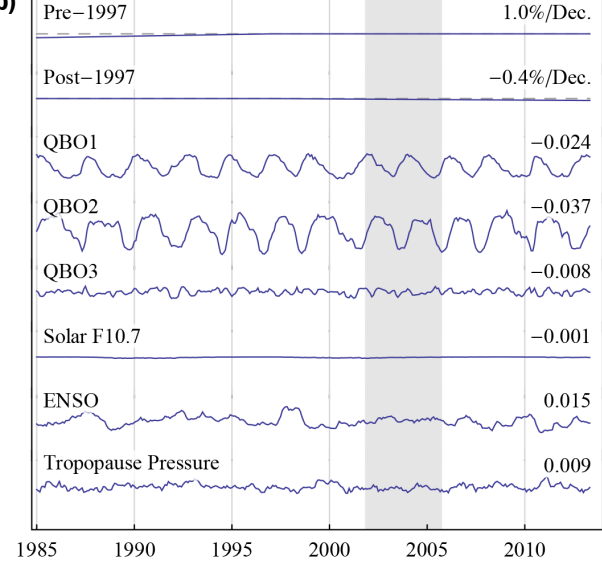

$1985-1990-1995 \quad 2000-2005 \quad 2010$

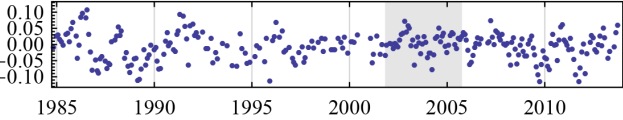

Figure 8. Same as Fig. 6. Left: $45^{\circ} \mathrm{S}-35^{\circ} \mathrm{S}$ at $42.5 \mathrm{~km}$ altitude. The strongest change between pre- and post-1997 linear trends occurs in this region and similarly for the Northern Hemisphere at these latitudes. Right: $5^{\circ} \mathrm{S}-5^{\circ} \mathrm{N}$ at $32.5 \mathrm{~km}$ altitude. In this region, the linear trends are reversed in direction compared to the remainder of the stratosphere, but are statistically insignificant.
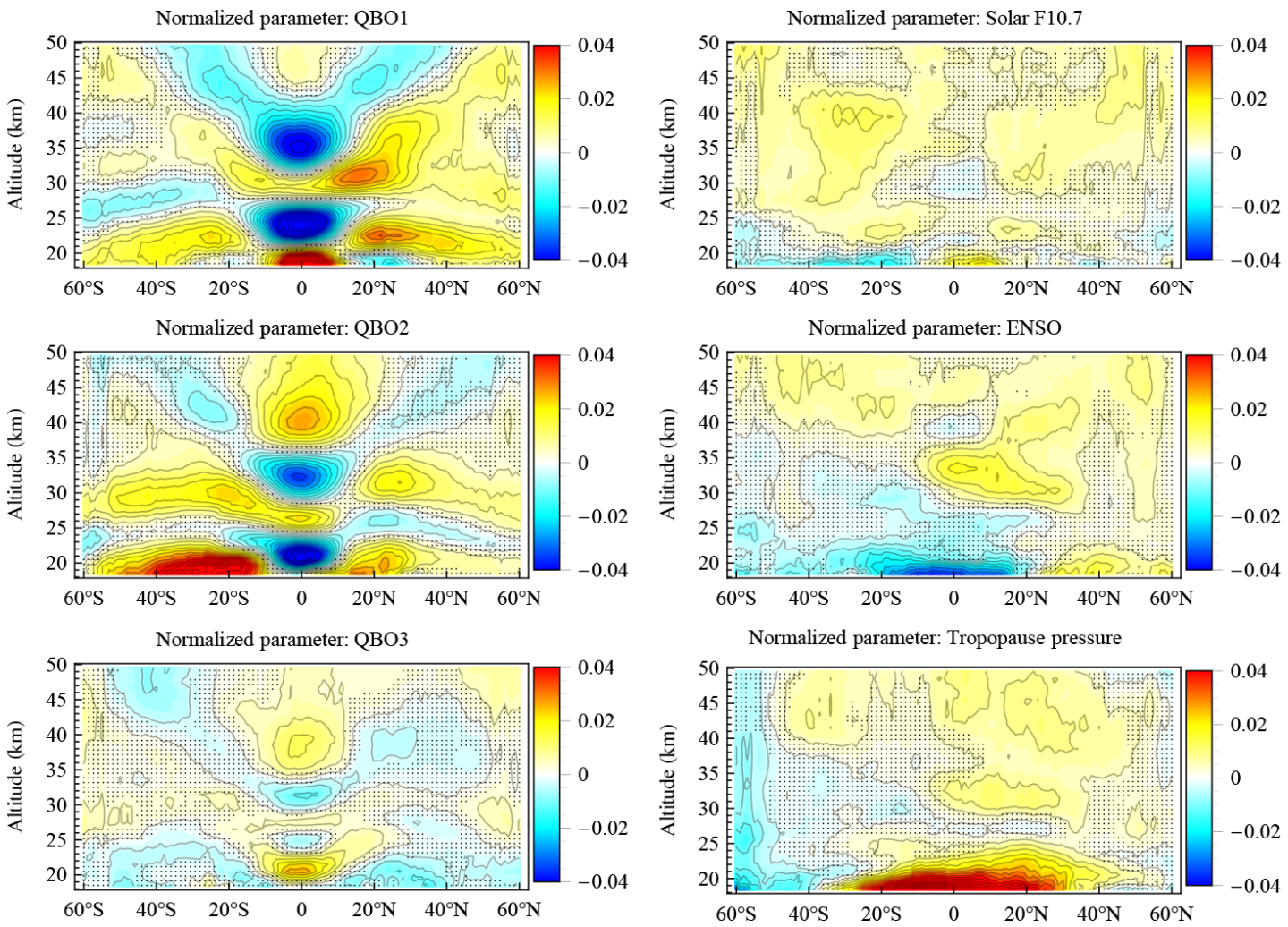

Figure 9. Altitude-latitude cross sections of the normalized fit parameter values for the six predictor basis functions. The units are relative ozone change per one standard deviation of the predictor time series. Regions that are not statistically significant at the $95 \%$ level are shown with overlaid grey stippling. In general, throughout the stratosphere the greatest contribution to the relative ozone anomaly comes from the first two principal components of the QBO index. 

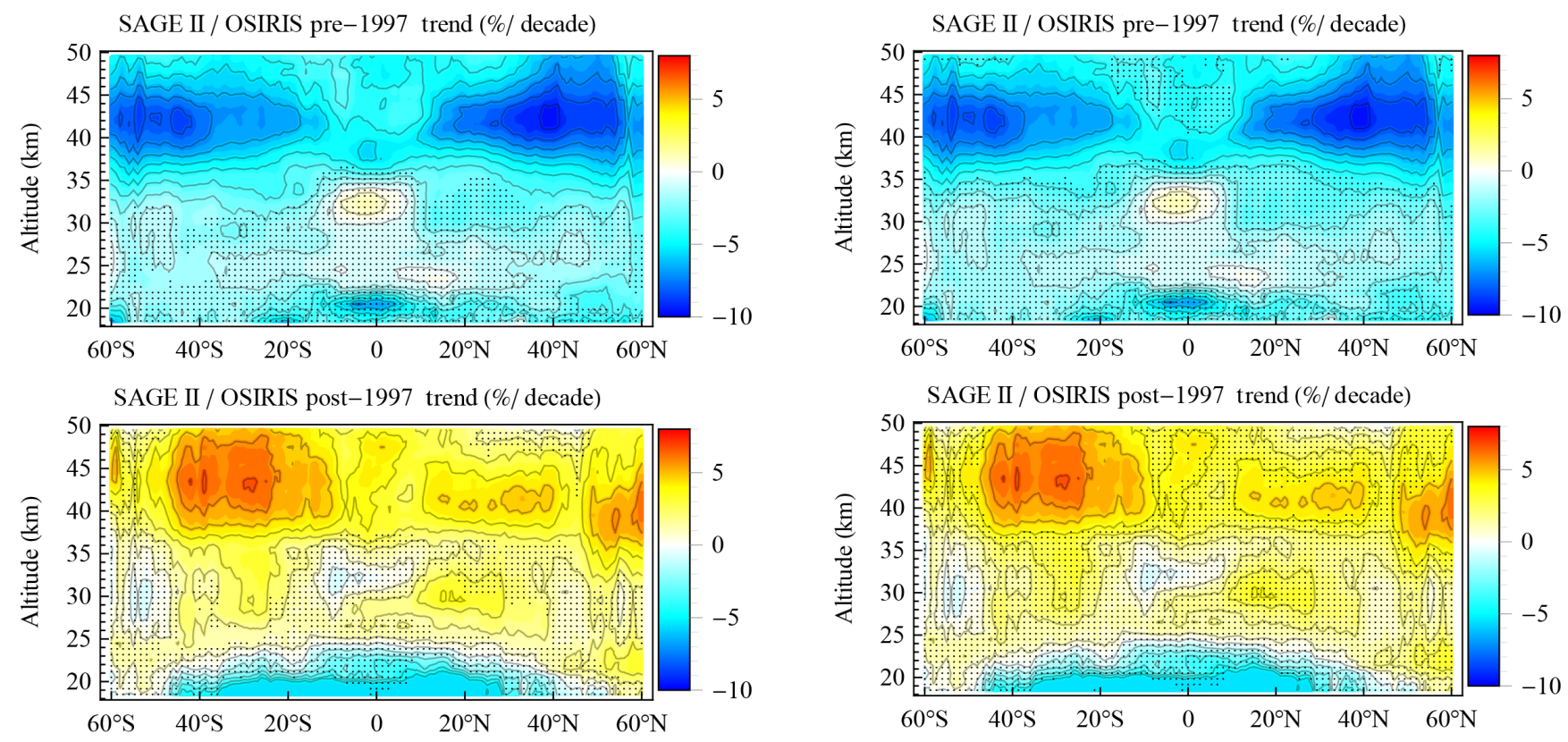

Figure 10. Altitude-latitude cross section of linear ozone trends in percent per decade before 1997 (top) and after 1997 (bottom) derived from the merged SAGE II and OSIRIS ozone anomaly time series. Statistical significance at the $95 \%$ level is denoted by areas without grey stippling. Significant recovery is observed throughout the majority of the stratosphere, except below approximately $22 \mathrm{~km}$ altitude between $40^{\circ} \mathrm{S}$ and $40^{\circ} \mathrm{N}$ where decreasing trends continue and in the tropics between 25 and $35 \mathrm{~km}$ where there is no significant trend.

not show the decreasing trend in the lower stratosphere. Eckert et al., 2014, also performed similar analyses using the MIPAS (Michelson Interferometer for Passive Atmospheric Sounding) measurements alone from 2002 to 2012. These results show recovery in the midlatitude upper stratosphere and a small region of significant negative trends in the tropical stratosphere near $30 \mathrm{~km}$, though with smaller magnitude than that found with SCIAMACHY, and no significant trend below $20 \mathrm{~km}$.

This study has demonstrated the feasibility of merging the SAGE II and OSIRIS ozone profile records into a single time series from 1984 to present for the purpose of assessing variability and trends in stratospheric ozone. The data sets each have high quality and high vertical resolution with small drifts in comparison to other instruments. There is excellent agreement between the two data sets during the 4year overlap period, 2002-2005, which enhances confidence in the ability to reliably merge the two records. Analysis of the time series of monthly and zonally averaged values shows that both instruments correlate well throughout the stratosphere from $60^{\circ} \mathrm{S}$ to $60^{\circ} \mathrm{N}$ and agree to within typically $5 \%$. An instrument-independent deseasonalization of each time series is used to merge the data sets into a single time series of interannual ozone anomalies spanning the period 1984-

Figure 11. The same linear trends in ozone in the post-1997 period as those shown in Fig. 10, but with the significance interval modified to account for potential drift in the OSIRIS measurements.

2013. A multivariate linear regression is then used to assess the remaining variability in terms of predictor basis functions including the QBO, ENSO index, tropical tropopause pressure, solar proxy and a piece-wise linear term with fixed inflection at 1997. Our analyses capture the spatial patterns and magnitudes for the QBO, ENSO and solar variations in ozone reported in previous studies. The trend results show that from 1984 to 1997 there are statistically significant negative trends of 5-10\% per decade throughout the stratosphere above $30 \mathrm{~km}$, except over the tropics where a small and insignificant positive trend is found between 30 and $35 \mathrm{~km}$. In contrast, from 1997 to present a statistically significant ozone increase (recovery) of 3-8\% per decade has taken place throughout most of the stratosphere, with the notable exception below approximately $22 \mathrm{~km}$ altitude between $40^{\circ} \mathrm{S}$ and $40^{\circ} \mathrm{N}$ where decreasing trends continue, consistent with the tropical lower stratospheric trend reported by Sioris et al., 2013. The bootstrap uncertainty estimates are more conservative than those used by Sioris et al. and in this analysis the decreasing trend very near to the Equator is not significant. Sioris et al. also used a single linear trend throughout the entire time period and splitting the analysis into pre- and post-1997 time periods may also affect the significance of this decreasing trend. Thus the long-term negative trends in the tropical lower stratosphere appear distinctive from the reversible changes, i.e., ozone recovery, observed in the middle and upper stratosphere. 
Acknowledgements. This work was supported by the Natural Sciences and Engineering Research Council (Canada) and the Canadian Space Agency (CSA). Odin is a Swedish-led satellite project funded jointly by Sweden (SNSB), Canada (CSA), France (CNES) and Finland (Tekes).

Edited by: M. Weber

\section{References}

Adams, C., Bourassa, A. E., Bathgate, A. F., McLinden, C. A., Lloyd, N. D., Roth, C. Z., Llewellyn, E. J., Zawodny, J. M., Flittner, D. E., Manney, G. L., Daffer, W. H., and Degenstein, D. A.: Characterization of Odin-OSIRIS ozone profiles with the SAGE II dataset, Atmos. Meas. Tech., 6, 1447-1459, doi:10.5194/amt6-1447-2013, 2013.

Adams, C., Bourassa, A. E., Sofieva, V., Froidevaux, L., McLinden, C. A., Hubert, D., Lambert, J.-C., Sioris, C. E., and Degenstein, D. A.: Assessment of Odin-OSIRIS ozone measurements from 2001 to the present using MLS, GOMOS, and ozonesondes, Atmos. Meas. Tech., 7, 49-64, doi:10.5194/amt-7-49-2014, 2014.

Bogumil, K., Orphal, J., Homann, T., Voigt, S., Spietz, P., Fleischmann, O., Vogel, A., Hartmann, M., Kromminga, H., Bovensmann, H., Frerick, J., and Burrows, J.: Measurements of molecular absorption spectra with the SCIAMACHY pre-flight model: instrument characterization and reference data for atmospheric remote-sensing in the $230-2380 \mathrm{~nm}$ region, J. Photoch. Photobio. A, 157, 167-184, doi:10.1016/S1010-6030(03)00062-5, 2003.

Bourassa, A. E., Degenstein, D. A., and Llewellyn, E. J.: SASKTRAN: a spherical geometry radiative transfer code for efficient estimation of limb scattered sunlight, J. Quant. Spectrosc. Ra., 109, 52-73, doi:10.1016/j.jqsrt.2007.07.007, 2007.

Brönnimann, S., Luterbacher, J., Staehelin, J., Svendby, T. M., Hansen, G., and Svenoe, T.: Extreme climate of the global troposphere and stratosphere in 1940-42 related to El Nino, Nature, 431, 971-974, 2004.

Calvo, N., Garcia, R. R., Randel, W. J., and Marsh, D.: Dynamical mechanism for the increase in tropical upwelling in the lowermost tropical stratosphere during warm ENSO events, J. Atmos. Sci., 67, 2331-2340, doi:10.1175/2010JAS3433.1, 2010.

Chipperfield, M. P., Gray, L. J., Kinnersley, J. S., and Zawodny, J.: A two-dimensional model study of the QBO signal in SAGE II $\mathrm{NO}_{2}$ and $\mathrm{O}_{3}$, Geophys. Res. Lett., 21, 589-592, doi:10.1029/94GL00211, 1994.

Damadeo, R. P., Zawodny, J. M., Thomason, L. W., and Iyer, N.: SAGE version 7.0 algorithm: application to SAGE II, Atmos. Meas. Tech., 6, 3539-3561, doi:10.5194/amt-6-3539-2013, 2013.

Degenstein, D. A., Bourassa, A. E., Roth, C. Z., and Llewellyn, E. J.: Limb scatter ozone retrieval from 10 to $60 \mathrm{~km}$ using a multiplicative algebraic reconstruction technique, Atmos. Chem. Phys., 9, 6521-6529, doi:10.5194/acp-9-65212009, 2009.

Efron, B. and Tibshirani, R. J.: An Introduction to the Bootstrap, Chapman and Hall, New York, 436 pp., 1993.
Eckert, E., von Clarmann, T., Kiefer, M., Stiller, G. P., Lossow, S., Glatthor, N., Degenstein, D. A., Froidevaux, L., GodinBeekmann, S., Leblanc, T., McDermid, S., Pastel, M., Steinbrecht, W., Swart, D. P. J., Walker, K. A., and Bernath, P. F.: Drift-corrected trends and periodic variations in MIPAS IMK/IAA ozone measurements, Atmos. Chem. Phys., 14, 25712589, doi:10.5194/acp-14-2571-2014, 2014.

Gebhardt, C., Rozanov, A., Hommel, R., Weber, M., Bovensmann, H., Burrows, J. P., Degenstein, D., Froidevaux, L., and Thompson, A. M.: Stratospheric ozone trends and variability as seen by SCIAMACHY from 2002 to 2012, Atmos. Chem. Phys., 14, 831-846, doi:10.5194/acp-14-831-2014, 2014.

Harris, N. R. P., Hassler, B., Tummon, F., Bodeker, G. E., Petropavlovskikh, I., Fioletov, V. E., Steinbrecht, W., Davis, S. M., Wang, H. J., Froidevaux, L., Frith, S. M., Wild, J., Kyrölä, E., Sioris, C., and Zawodny, J.: SI2N overview paper: analysis and interpretation of changes in the vertical distribution of ozone, in preparation, 2014.

Jones, A., Urban, J., Murtagh, D. P., Eriksson, P., Brohede, S., Haley, C., Degenstein, D., Bourassa, A., von Savigny, C., Sonkaew, T., Rozanov, A., Bovensmann, H., and Burrows, J.: Evolution of stratospheric ozone and water vapour time series studied with satellite measurements, Atmos. Chem. Phys., 9, 6055-6075, doi:10.5194/acp-9-6055-2009, 2009.

Kyrölä, E., Laine, M., Sofieva, V., Tamminen, J., Päivärinta, S.-M., Tukiainen, S., Zawodny, J., and Thomason, L.: Combined SAGE II-GOMOS ozone profile data set for 1984-2011 and trend analysis of the vertical distribution of ozone, Atmos. Chem. Phys., 13, 10645-10658, doi:10.5194/acp-13-10645-2013, 2013.

Laine, M., Latva-Pukkila, N., and Kyrölä, E.: Analyzing time varying trends in stratospheric ozone time series using state space approach, Atmos. Chem. Phys. Discuss., 13, 20503-20530, doi:10.5194/acpd-13-20503-2013, 2013.

Llewellyn, E. J., Lloyd, N. D., Degenstein, D. A., Gattinger, R. L., Petelina, S. V., Bourassa, A. E., Wiensz, J. T., Ivanov, E. V., McDade, I. C., Solheim, B. H., McConnell, J. C., Haley, C. S., von Savigny, C., Sioris, C. E., McLinden, C. A., Griffioen, E., Kaminski, J., Evans, W. F. J., Puckrin, E., Strong, K., Wehrle, V., Hum, R. H., Kendall, D. J. W., Matsushita, J., Murtagh, D. P., Brohede, S., Stegman, J., Witt, G., Barnes, G., Payne, W. F., Piché, L., Smith, K., Warshaw, G., Deslauniers, D.-L., Marchand, P., Richardson, E. H., King, R. A., Wevers, I., McCreath, W., Kyrölä, E., Oikarinen, L., Leppelmeier, G. W., Auvinen, H., Mégie, G., Hauchecorne, A., Lefèvre, F., de La Nöe, J., Ricaud, P., Frisk, U., Sjoberg, F., von Schéele, F., and Nordh, L.: The OSIRIS instrument on the Odin spacecraft, Can. J. Phys., 82, 411-422, doi:10.1139/P04-005, 2004.

McCormick, M. P., Zawodny, J. M., Viega, R. E., Larson, J. C., and Wang, P. H.: An overview of SAGE I and II ozone measurements, Planet. Space Sci., 37, 1567-1586, doi:10.1016/00320633(89)90146-3, 1989.

McLinden, C. A. and Fioletov, V.: Quantifying trends in stratospheric ozone: complications due to stratospheric cooling, Geophys. Res. Lett., 38, L03808, doi:10.1029/2010GL046012, 2011.

McLinden, C. A., Bourassa, A. E., Brohede, S., Cooper, M., Degenstein, D. A., Evans, W. J. F., Gattinger, R. L., Haley, C. S., Llewellyn, E. J., Lloyd, N. D., Loewen, P., Martin, R. V., McConnell, J. C., McDade, I. C., Murtagh, D., Rieger, L., von Savigny, C., Sheese, P., Sioris, C. E., Solheim, B., and Strong, K.: 
OSIRIS: a decade of scattered light, B. Am. Meteorol. Soc., 93, 1845-1863, doi:10.1175/BAMS-D-11-00135.1, 2012.

Murtagh, D., Frisk, U., Merino, F., Ridal, M., Jonsson, A., Stegman, J., Witt, G., Eriksson, P., Jiménez, C., Megie, G., de la Noë, J., Ricaud, P., Baron, P., Pardo, J. R., Hauchcorne, A., Llewellyn, E. J., Degenstein, D. A., Gattinger, R. L., Lloyd, N. D., Evans, W. F. J., McDade, I. C., Haley, C. S., Sioris, C., von Savigny, C., Solheim, B. H., McConnell, J. C., Strong, K., Richardson, E. H., Leppelmeier, G. W., Kyrölä, E., Auvinen, H., and Oikarinen, L.: An overview of the Odin atmospheric mission, Can. J. Phys., 80, 309-319, 2002.

Naujokat, B.: An update of the observed quasi-biennial oscillation of the stratospheric winds over the tropics, J. Atmos. Sci., 43, 1873-1877, 1986.

Newchurch, M. J., Yang, E.-S., Cunnold, D. M., Reinsel, G. C., Zawodny, J. M., and Russell, J. M.: Evidence for slowdown in stratospheric ozone loss: first stage of ozone recovery, J. Geophys. Res.-Atmos., 108, 4507, doi:10.1029/2003JD003471, 2003.

Randel, W. J. and Wu, F.: Isolation of the ozone QBO in SAGE II data by singular value decomposition, J. Atmos. Sci., 53, 2546-2559, doi:10.1175/15200469(1996)053<2546:IOTOQI>2.0.CO;2, 1996.

Randel, W. J. and Wu, F.: A stratospheric ozone profile data set for 1979-2005: Variability, trends, and comparisons with column ozone data, J. Geophys. Res., 112, D06313, doi:10.1029/2006JD007339, 2007.

Randel, W. J., Garcia, R. R., Calvo, N., and Marsh, D.: ENSO influence on zonal mean temperature and ozone in the tropical lower stratosphere, Geophys. Res. Lett., 36, L15822, doi:10.1029/2009GL039343, 2009.

Randel, W. J. and A. M. Thompson: Interannual variability and trends in tropical ozone derived from SAGE II satellite data and SHADOZ ozonesondes, J. Geophys. Res., 116, D07303, doi:10.1029/2010JD015195, 2011.

Rienecker, M. M., Suarez, M. J., Gelaro, R., Todling, R., Bacmeister, J., Liu, E., Bosilovich, M. G., Schubert, S. D., Takacs, L., Kim, G.-K., Bloom, S., Chen, J., Collins, D., Conaty, A., da Silva, A., Gu, W., Joiner, J., Koster, R. D., Lucchesi, R., Molod, A., Owens, T., Pawson, S., Pegion, P., Redder, C. R., Reichle, R., Robertson, F. R., Ruddick, A. G., Sienkiewicz, M., and Woollen, J.: MERRA: NASA's Modern-Era Retrospective Analysis for research and applications, J. Climate, 24, 3624-3648, doi:10.1175/JCLI-D-11-00015.1, 2011.
Sioris, C. E., McLinden, C. A., Fioletov, V. E., Adams, C., Zawodny, J. M., Bourassa, A. E., and Degenstein, D. A.: Trend and variability in ozone in the tropical lower stratosphere over 2.5 solar cycles observed by SAGE II and OSIRIS, Atmos. Chem. Phys. Discuss., 13, 16661-16697, doi:10.5194/acpd-13-166612013, 2013.

von Savigny, C., Sioris, C. E., McDade, I. C., Llewellyn, E. J., Degenstein, D., Evans, W. F. J., Gattinger, R. L., Griffioen, E., Kyrölä, E., Lloyd, N. D., McConnell, J. C., McLinden, C. A., Mégie, G., Murtagh, D. P., Solheim, B., and Strong, K.: Stratospheric ozone profiles retrieved from limb scattered sunlight radiance spectra measured by the OSIRIS instrument on the Odin satellite, Geophys. Res. Lett., 30, 1755, doi:10.1029/2002GL016401, 14, 2003.

Wallace, J. M., Panetta, R. L., and Estberg, J.: Representation of the equatorial quasi-biennial oscillation in EOF phase space, J. Atmos. Sci., 50, 1751-1762, doi:10.1175/1520-0469, 1993.

Weatherhead, E. C., Reinsel, G. C., Tiao, G. C., Jackman, C. H., Bishop, L., Hollandsworth Firth, S. M., Deluisi, J., Keller, T., Oltmans, S. J., Fleming, E. L., Wuebbles, D. J., Kerr, J. B., Miller, A. J., Herman, J., and McPeters, R.: Detecting the recovery of total column ozone, J. Geophys. Res., 105, 22201-22210, 2000.

Wang, H. J.: Assessment of SAGE version 6.1 ozone data quality, J. Geophys. Res., 107, 1-18, doi:10.1029/2002JD002418, 2002.

Wolter, K.: Multivariate ENSO Index (MEI), available at: www.cdc. noaa.gov/people/klaus.wolter/MEI/ (last access: October 2013), 2013.

WMO: Scientific Assessment of Ozone Depletion: 2010, Global Ozone Research and Monitoring Project - Report No. 52, World Meteorological Organization, Geneva, Switzerland, 2011. 